\title{
APPLICATION OF TECHNOLOGIES OF FORMAL AND NON-FORMAL EDUCATION FOR CONTINUOUS PROFESSIONAL DEVELOPMENT OF THE MODERN SPECIALIST
}

APLICAÇÃO DE TECNOLOGIAS DE EDUCAÇÃO FORMAL E NÃO FORMAL PARA O DESENVOLVIMENTO PROFISSIONAL CONTÍNUO DO ESPECIALISTA MODERNO

\section{APLICACIÓN DE TECNOLOGÍAS DE EDUCACIÓN FORMAL Y NO FORMAL PARA EL DESARROLLO PROFESIONAL CONTINUO DEL ESPECIALISTA MODERNO}

\author{
Viktoriia V. Sydorenko ${ }^{1}$ \\ Inna M. Shorobura ${ }^{2}$ \\ Anna Yu. Ponomarenko ${ }^{3}$ \\ Maryna O. $\mathrm{Dei}^{4}$ \\ Oksana V. Dzhus ${ }^{5}$
}

\begin{abstract}
The article considers the technology of formal and non-formal education as a factor of improving the quality, efficiency and effectiveness of lifelong learning of adults, their continuous personal and professional self-development and self-realization in accordance with an individual educational trajectory. In the study, the following methods were used: expert survey, interview, questionnaire, testing, observation, analysis of documents. The content, essence, principles of application of interactive, acmeological, andragogical and digital technologies are described, which ensure the effective functioning of the content of adult learning, meet the interests, requests and needs of customers of educational services, employers and key stakeholders. On the basis of comprehensive permanent monitoring, the effectiveness of the use of continuing education technologies for the training of a modern specialist has been experimentally tested. The results of the research can be used in the process of modernizing the system of continuing education, the organization of adult lifelong learning.
\end{abstract}

Keywords: Sustainable Development. Formal Education. Continuous Development. Adult Teaching Technologies.

Resumo: O artigo considera a tecnologia da educação formal e não formal como fator de melhoria da qualidade, eficiência e eficácia da aprendizagem ao longo da vida de adultos, seu contínuo

\footnotetext{
${ }^{1}$ University of Educational Management. Bila Tserkva, Ukraine.

${ }^{2}$ Khmelnytskyi Humanitarian and Pedagogical Academy. Khmelnytskyi, Ukraine.

${ }^{3}$ National Academy of the Security Service of Ukraine. Kyiv, Ukraine.

${ }^{4}$ National Aviation University. Kyiv, Ukraine.

${ }^{5}$ Vasyl Stefanyk Precarpathian National University. Ivano-Frankivsk, Ukraine.
} 
autodesenvolvimento e autorrealização pessoal e profissional de acordo com a trajetória educacional individual. No estudo, foram utilizados os seguintes métodos: perícia, entrevista, questionário, teste, observação, análise de documentos. São descritos o conteúdo, a essência, os princípios de aplicação das tecnologias interativas, que garantem o funcionamento eficaz dos conteúdos de educação de adultos, atendem aos interesses, solicitações e necessidades dos clientes de serviços educacionais, empregadores e principais stakeholders. Com base em um monitoramento permanente abrangente, a eficácia do uso de tecnologias de educação permanente para a formação de um especialista moderno foi testada experimentalmente. Os resultados da pesquisa podem ser utilizados no processo de modernização do sistema de educação continuada, a organização da aprendizagem ao longo da vida de adultos.

Palabras clave: Desenvolvimento sustentável. Educação formal. Desenvolvimento contínuo. Tecnologias de ensino de adultos.

Resumen: El artículo considera la tecnología de la educación formal y no formal como un factor de mejora de la calidad, eficiencia y efectividad del aprendizaje permanente de los adultos, su continuo autodesarrollo y autorrealización personal y profesional de acuerdo con una trayectoria educativa individual. En el estudio se utilizaron los siguientes métodos: encuesta a expertos, entrevista, cuestionario, análisis de documentos. Se describen el contenido, la esencia, los principios de aplicación de las tecnologías interactivas, satisfacen los intereses, solicitudes y necesidades de los clientes de los servicios educativos, empleadores y partes interesadas clave. Sobre la base de un monitoreo permanente integral, se ha probado experimentalmente la efectividad del uso de tecnologías de educación continua para la formación de un especialista moderno. Los resultados de la investigación se pueden utilizar en el proceso de modernización del sistema de educación continua, la organización del aprendizaje permanente de adultos.

Palavras-chave: Desarrollo sostenible. Educación formal. Desarrollo continuo. Tecnologías de enseñanza para adultos.

Resumo: El artículo considera la tecnología de la educación formal y no formal como un factor de mejora de la calidad, eficiencia y efectividad del aprendizaje permanente de los adultos, su continuo autodesarrollo y autorrealización personal y profesional de acuerdo con una trayectoria educativa individual. En el estudio se utilizaron los siguientes métodos: encuesta a expertos, entrevista, cuestionario, análisis de documentos. Se describen el contenido, la esencia, los principios de aplicación de las tecnologías interactivas, satisfacen los intereses, solicitudes y necesidades de los clientes de los servicios educativos, empleadores y partes interesadas clave. Sobre la base de un monitoreo permanente integral, se ha probado experimentalmente la efectividad del uso de tecnologías de educación continua para la formación de un especialista moderno. Los resultados de la investigación se pueden utilizar en el proceso de modernización del sistema de educación continua, la organización del aprendizaje permanente de adultos.

Palavras-chave: Desarrollo sostenible. Educación formal. Desarrollo continuo. Tecnologías de enseñanza para adultos.

\section{INTRODUCTION}

Philosophical understanding of the educational processes of our time and their corresponding perspective transformations of epochal nature in the future gives the reasons to 
justify this phenomenon as a "paradigmatic revolution in education" (Framework for updated key..., 2019). It is not for nothing that the law of general priority of education, which is the basis of intellectual, spiritual, physical and cultural development of the individual, his/her successful socialization, the key to sustainable development of society and the state, has become powerful in the world. A peculiar response to the civilizational-historical and educational challenges of the XXI century is a rethinking of basic principles, values of professional development throughout life through formal, non-formal and informal education, the formation of competencies necessary for successful self-realization in the profession and life (A Memorandum on Lifelong Learning..., 2000).

According to Article 18 of the Law of Ukraine No 2145-VIII “On Education” (2017), continuous professional development is interpreted as a continuous process of training and improving the professional competencies of professionals after higher and/or postgraduate education, which allows them to maintain or improve professional standards and lasts throughout his/her professional career. In the conditions of continuous education professional development of specialists is a complex multilevel, prolonged, step-by-step and ambivalent process, as it is possible to observe its unevenness and heterochrony at all stages, violation of linearity, sequence and order, stages of bifurcation.

Professional development involves the formation of a qualified specialist, professional, personality, who goes through periods of professional adaptation, gaining empirical experience, formation and improvement of professionalism. Training of specialists using formal and non-formal education technologies should be based on competency, personality-oriented and andragogical approaches (Knowles et al., 2020; Buribayev \& Khamzina, 2019). With preference given to the subjective activity of an adult student who independently models and implements individual educational trajectory parameters of the learning process. In particular, the content, duration, forms, methods, programs, tools, etc., carries out goal-setting and constructive correction in fundamentally new conditions, variably forecasts the results of activities, etc.

Technologies of formal and non-formal adult education are aimed at realizing personal and professional abilities of a specialist as a subject of professional activity, development of his inner potential (State standard of Ukraine..., 2014). The selection of continuing education technologies means the choice of strategy, priorities, system of interaction of all subjects, tactics of adult learning and appropriate style of work taking into account andragogical principles. It involves planning, organization, application and evaluation of the process and results of professional development (Buribayev et al., 2020; Khamzina et al., 2020). The components of adult learning technologies are 
the concept, content of education, procedural characteristics, appropriate scientific and methodological support for professional development of specialists and innovative scientific and methodological support (The concept of implementation..., 2019). The criterion indicators are the guaranteed effectiveness of the educational process; positive changes in the development of the subjects, adequate to the set goals; purposefulness, pre-designed and guaranteed current and final results; controllability; systematic didactic tools; reproducibility, etc.

Thus, we consider formal and non-formal education technologies as a factor in improving the quality, efficiency and effectiveness of continuing education, increasing demand for various educational services, changing motivational readiness and ability of professionals to learn throughout life. The purpose of the article is a thorough study of formal and non-formal education technologies for extrapolation of the main theoretical and methodological provisions for the training of a modern specialist, a professional in the system of continuing education. In accordance with the purpose, the main objectives of the study are defined as follows:

- to analyze the basic principles, approaches and features of professional development of specialists;

- to describe interactive, acmeological, andragogical and digital technologies that ensure the effective functioning of learning content;

- to select and experimentally test the effectiveness of the use of formal and non-formal education technologies for continuous professional development of specialists throughout life;

- to conduct comprehensive permanent monitoring of the feasibility of selection and use of technologies of formal and non-formal education for the training of modern specialists, professionals.

\section{MATERIALS AND METHODS}

In order to monitor the process of continuous professional development of specialists, forecasting and implementation of innovative scientific and methodological support, we used a comprehensive permanent monitoring, which was conducted as a single study on certain priority areas, criteria, indicators. We understand the term "monitoring", as the system of control and psychological and andragogical diagnosis, which provides a set of procedures for monitoring (collection, processing, storage and dissemination of information), current assessment of important 
transformations in the educational system. Comprehensive permanent monitoring was conducted on:

- individual basis (self-assessment by the subjects of monitoring of the level of professional development, formation of competencies);

- local (related to the organization and conduct of research, collection of information within individual experimental institutions);

- municipal (local education authorities, educational methodical centers of vocational education assessed the dynamics of professional development of specialists through the use of formal and non-formal education technologies, identified problems and future prospects);

- regional levels (monitored the development of educational facilities at the regional, city, district, clarified the effectiveness of continuing education technologies).

The study was performed on the basis of the Bila Tserkva Institute of Continuing Professional Education of the National Academy of Pedagogical Sciences of Ukraine. 4982 people from 19 regions of Ukraine and Kyiv took part in the formation and control stages of the experiment. Training and methodological centers of vocational education in Volyn, Zakarpattia, Donetsk, Dnipropetrovsk, Zhytomyr, Kirovohrad, Luhansk, Mykolaiv, Odesa, Poltava, Sumy, Chernihiv, Cherkasy, Kherson, Kharkiv regions and an educational and methodical office in Kyiv were involved in conducting monitoring studies of the quality of professional development of specialists through formal and nonformal education. The following methods were used to collect primary information: expert survey, interview, questionnaire, testing, observation; analysis of documents, assessment of the level of achievement of learning outcomes in advanced training courses and in the intercourse period.

The use of technologies for monitoring and assessing the satisfaction of customers of educational services and key stakeholders helps to ensure the quality of professional development and achieve competitive advantages in the market of educational services. An advisory monitoring was conducted, which, according to the European Union's ERASMUS + program, should focus on studying the partnership, planning and implementing planned activities, priorities, methodology, implementation of tasks and achievement of results. Assessment and study of the dynamics of professional development of specialists through the use of formal and informal education technologies was based on ten indicators, in particular:

- development/improvement of competencies in accordance with the requirements of the labor market, employers and key stakeholders;

- quality of organization of the educational process; 
- the level of use of digital technologies in the educational process,

- practical orientation of the content of advanced training;

- innovative scientific and methodological support of the educational process (accessibility, clear logical sequence of presentation, connection of educational material with practical professional activity, novelty, address orientation, connection of course and intercourse period, etc.);

- general quality of teaching modules, special courses at advanced training courses;

- the degree of satisfaction of requests and needs of students for the latest production technologies;

- compliance of the content of training with the professional needs of students;

- comfortable psychological conditions during the educational process;

- introduction of learning outcomes into the practice of professional activity.

\section{RESULTS AND DISCUSSION}

\subsection{FEATURES OF FORMAL AND NON-FORMAL EDUCATION TECHNOLOGIES IN THE SYSTEM OF CONTINUOUS PROFESSIONAL DEVELOPMENT}

Lifelong professional development takes place through adult learning technologies through formal, non-formal and informal education (Towards an institutional strategy..., 2012). The technology of adult teaching is a system of scientifically based andragogical, human-centered and acmeological principles of learning the actions of adult students. It provides training of an innovative specialist, comprehensively harmonious personality, a professional capable of choosing an individual educational trajectory, lifelong professional development through formal, non-formal and informal education (Ridho et al., 2018). Professional development of adults as a holistic system includes the following components: the needs of learners, professionally improved (real, conscious), purpose and objectives (specific and achievable), content (relevant, applied, competence, humancentered), technology (formal and non-formal education, in particular interactive, andragogical, acmeological, digital, etc.), means (contemporary), results (measurable).

It should be noted that for the effective organization of continuous professional development of a modern specialist throughout life through formal and non-formal education, it is necessary to take into account the initial positions of adult learning (Knowles et al., 2020): 
- the subject of education has a leading role;

- the adult strives for self-realization, independence, self-management and realizes himself/herself as such;

- an adult learner has competency experience (domestic, social, professional), which can be used as an important source of teaching for themselves and for colleagues;

- the main type of educational work of adult students is the independent implementation of the organization of the learning process;

- an adult learns to solve an important life problem and achieve a specific professional goal;

- expects on the immediate application of skills, abilities, knowledge and acquired qualities in the learning process;

- the educational activity of an adult is determined by temporal, spatial, domestic, professional, social factors that either limit or help the learning process;

- the process of adult learning is organized as a joint activity of subjects of learning at all stages: planning, implementation, evaluation, adjustment, includes effective communication, positive atmosphere, network for professional exchange of knowledge and experience. It including interaction of educational institutions with partners (higher educational institution, institutes of postgraduate education; city (district) methodical offices (centers); specialists-trainers, tutors, experts, scientific institutions, public organizations, international projects, etc.).

The professional development of a modern specialist should be organized with the use of modern technologies of formal, non-formal and informal education and taking into account the basic system-forming principles of open education, in particular (Government approves state..., 2018):

- promoting the sustainable development of society by preparing competitive human capital and creating conditions for lifelong learning;

- human(student)centered teaching, for which the educational process is created taking into account individual capabilities, abilities, professional needs, sensitive periods of personality development;

- continuity, which provides for the organization of systematic and purposeful development of competencies of specialists to increase personal potential, expand employment opportunities, social integration and active citizenship through formal, non-formal and informal learning; 
- consistency - a set of interconnected elements, including goals, conditions, factors, organizational, substantive, diagnostic and regulatory support, which allows for consistent, holistic, logically ordered and structured, continuous professional development;

- variability, which provides a combination of flexibility, the ability to choose parameters, content, methods, sources, terms, pace of learning on an individual educational trajectory, which makes the learning system effective, economical and interesting;

- advanced professional development, which enables the improvement of educational and professional skills and further professional development of specialists in accordance with innovative social and educational challenges, European and state standards;

- academic integrity as a set of ethical principles and rules defined by the Law of Ukraine No 2145-VIII “On Higher Education” (2017), which should guide the participants of the educational process during the process of learning, teaching and conducting scientific (creative) activities in order to ensure trust to learning outcomes and/or scientific (creative) achievements;

- academic mobility, which includes the opportunity for participants in the educational process to study, teach, train or conduct research in another institution of higher education (scientific institution) in Ukraine or abroad;

- academic freedom - independence and autonomy of participants in the educational process during the pedagogical, scientific-pedagogical, scientific and/or innovative activities carried out on the principles of freedom of speech and creativity, dissemination of knowledge and information, research and use of their results and implemented with subject to the restrictions established by law;

- network activities, i.e. interaction and cooperation of all subjects on the basis of scientific and methodological management;

- individualization and differentiation, which allows planning and implementation of individual educational trajectory taking into account professional experience, capabilities, abilities, individual style of professional activity of customers of educational services;

- processability, which involves the use of effective andragogical technologies (interactive, training, acmeological, game technologies, psychophysiological, etc.), methods and techniques, forms of active interaction of the subjects of the educational process; 
- scientific and methodological support - the principle consists in continuously support creative initiatives, innovations, effective scientific, informational, subject-methodical, professional and qualification support of the process of self-improvement and self-realization, professional motivation to perform professional roles and functions;

- monitoring of quality, which provides an opportunity to measure and evaluate the professional dynamics of professional development of the specialist.

Technologies of formal postgraduate education are focused on the demands and needs of consumers of educational services - managers, teachers, research staff, based on the developed structural models of professional development (single-stage, two-stage, three-stage), which take into account forms and terms of study, volumes and content of educational and professional programs and category of students. The main forms of professional development are: full-time training; distance form of training; full-time-distance form; correspondence form; internship; individual (pedagogical patronage, in the workplace).

Non-formal education is education that is obtained through educational programs and does not involve the award of state-recognized educational qualifications by level of education, but may end with the award of professional and/or partial educational qualifications (Law of Ukraine..., 2018). This education is institutionalized, purposeful, and is additional, alternative and/or complementary to formal education in the process of lifelong learning. It can be short-term, low or high intensity, in particular in the form of short-term courses, seminars, workshops, practical classes. Non-formal education has no age, professional or intellectual restrictions on participants, often not limited in time (Sydorenko \& Denysova, 2020; Vinichenko et al., 2018a).

The field of non-formal education includes individual classes under the guidance of andragogues, coaches, moderators, educational advisors, trainings and short-term courses that pursue practical short-term goals. A specialist could obtain formal qualifications by mastering a certain set of individual programs of non-formal education and the corresponding recognition by the authorized body of the acquired knowledge, skills, competencies. Among the technologies of formal and non-formal education, which ensure the effective functioning of the content of education, meet the interests and demands for knowledge and learning time of adults, we distinguish interactive, acmeological, andragogical and digital. 
Interactive technologies of professional development of specialists are technologies of continuous education that ensure the inclusion of specialists in the learning process through the selection and use of a set of interactive forms, methods, techniques, teaching aids that allow to achieve the planned professional result, to ensure optimal consideration of learners, networking, etc. (Vinichenko et al., 2018b). The importance of using interactive technologies for the professional development of a specialist is explained by several reasons, including socio-economic (requirements of the labor market, employers and key stakeholders to train a comprehensively harmonious personality, competitive specialist, active development of new, more complex types of professional activity throughout the professional development, construction of socio-cultural relations between people, etc.); scientific (taking into account a new type of rationality for understanding spiritual and material activities, values); educational (building an open system of continuous professional development of the individual throughout life and building priorities along the way).

Acmeological technologies (acmetechnologies) - technologies of adult education aimed at realizing personal and professional abilities of a specialist as a subject of professional activity, development of his inner potential, adaptive opportunities in modern socio-cultural environment, search for effective ways of professional development on individual educational trajectory, selfrealization professional and personal acme (Sydorenko, 2016; Sydorenko \& Ponomarevskyi, 2018; Vinichenko et al., 2018c). Moreover, the psychological aspect (emotions, will, perception, thinking, mental regulation, etc.); physiological (functional states, individual differences, etc.); medical (psychotherapy, psychohygiene, psychoprophylaxis, psychocorrection, etc.); aspects of acmeological technologies allow to model and to develop intellectual, emotional, volitional culture of mental activity of the specialist; socio-psychological, pedagogical, managerial, ethical communicative and professional culture of business and interpersonal communication, professional interaction; ecological, legal, sociological aspects - social and moral and ethical norms, etc.

The task of acmetechnologies is to form and consolidate in the self-consciousness of the individual the need for continuous professional development through self-knowledge, selfimprovement, self-realization, achieved by special techniques and techniques, to exercise acmeological influence, which helps to reveal the creative potential of the specialist (Sydorenko, 2017; Vinichenko et al., 2018d). Acmeological technologies of self-knowledge, self-development and self-realization, by means of which the pedagogical worker develops as a subject of professional activity, form the technological basis of his positive-harmonious self-concept, which includes "self- 
image", "self-action", "self-attitude", "self-instruction" (Sydorenko, 2018). Among acmeological technologies we distinguish the following: acmeological design, acmeological analysis, acmeogram (individual educational trajectory), acmeological modeling, acmeographic description, psychological andragogical diagnostics, acmeological counseling, sensitivities, trainings, professional development self-regulation, leadership, creative qualities, etc.).

The main purpose of the use of digital technologies is the development of digital competence of specialists. It involves: improving and acquiring skills and abilities of confident, critical and responsible use and interaction with digital technologies for education, work and participation in modern knowledge society; information literacy, communication and cooperation, creation of digital content; ability to use digital technologies to support creativity, active citizenship and social integration, cooperation with other people to achieve personal, social goals; introduction to the main digital trends based on the use of digital technologies of the Internet of things, robotics and cybersystems, artificial intelligence, big data, paperless technologies, additive technologies (3Dprinting), cloud and fog computing, virtual and augmented reality technologies and biometric technologies identification technologies. In the Framework Program of renewed key competences for lifelong learning, approved by the European Parliament and the Council of the European Union on 17 January 2018 (ANNEX to the Proposal..., 2019), digital competence is substantiated as key, necessary for personal development and development, employment opportunities, social integration and active citizenship. No wonder digital literacy (or digital competence) is recognized by the EU as one of the keys to a full life and human activity. The Law "On Education" (2017) stipulates that the formation of information and communication competence is mandatory. Among the key competencies of the teacher of the New Ukrainian School, information and digital competence is singled out (Hryshchenko, 2017).

Among the digital technologies used in the process of formal and non-formal adult education, the most common are the following:

- Digital technologies of collective communication. Video conferencing technologies (for example, myownmeeting.net, myownconference.com.ua, zoom.us, Skype, jitsi.org, youtube.com) for online events in video and audio formats, namely online classes, web conferences, meetings of departments; 
- Google's cloud technologies for working with documents, developing calendars to visualize the timing and stages of project implementation, analytics and feedback on the quality of educational services.

- Social networks, in particular Facebook, Instagram for the exchange of personal profiles, as well as the reporting of both news and scientific, legislative, regulatory and public news in the field of education.

- YouTube, both for conducting scientific and educational events online, and saving for the possibility of further viewing.

- Cybersecurity technologies include the use of software to ensure the information security of the Institute and personal computers of employees.

- Digital technologies of academic integrity analysis, in particular the use of plagiarism analysis programs https://www.copyscape.com/, https://unicheck.com/, https://www.plag.lv/ and others.

- Technologies for visualization of educational content, such as multimedia presentations, infographics, video infographics, intelligence maps, timelines, QR codes, word clouds, scribing, gamification, 3d modeling, augmented (AR) and virtual (VR) reality, video.

- E-testing technologies and analytics in the educational process, including the use of e-tests, the introduction of Plickers as a cloud-based frontal survey technology, e-tests Google Forms, Master Test, Quizlet, Online Test Pad, Theory, etc.

- Creation of profiles of scientific and pedagogical workers in scientific and scientometric databases - ORCID, Web of Science, Google Scholar, Electronic Library of the National Academy of Pedagogical Sciences of Ukraine.

\subsection{THE INFLUENCE OF THE LMS "PROFOSVITA" ON THE ORGANIZATION PROFESSIONAL DEVELOPMENT OF THE MODERN SPECIALIST}

The effectiveness of the use of formal and non-formal education technologies for the professional development of modern specialists has been experimentally tested on the basis of the Bila Tserkva Institute of Continuing Professional Education of the National Academy of Pedagogical 
Sciences of Ukraine. The sample of the study consists of teachers from 19 regions of Ukraine and Kyiv, who took advanced training courses, participated in inter-course activities. The period of the control phase of the experiment was January - June 2020. A total of 4982 peoples were involved in the formative and control stages of the experiment, including: 2382 - students of advanced training courses (658 people - by state order; 1724 - at the expense of individuals and legal entities), 2600 people who took part in the intercourse period (see Table 1).

Table 1 - Number of students of advanced training courses for the first semester of 2020

\begin{tabular}{|c|c|c|c|}
\hline No & Categories of students & $\begin{array}{l}\text { Number of students of } \\
\text { advanced training courses }\end{array}$ & Form of education \\
\hline \multicolumn{4}{|c|}{ Advanced training by state order } \\
\hline \multirow[t]{2}{*}{1} & Senior masters of professional (vocational) & - & correspondence form \\
\hline & & - & full-time-distance form \\
\hline \multirow[t]{3}{*}{2} & $\begin{array}{l}\text { Masters of industrial training of professional } \\
\text { (vocational) education }\end{array}$ & 26 & full-time training \\
\hline & & 211 & correspondence form \\
\hline & & 160 & full-time-distance form \\
\hline \multirow[t]{3}{*}{3} & Teachers of professional and theoretical & 25 & full-time training \\
\hline & (vocational) education & 120 & correspondence form \\
\hline & & 116 & full-time-distance form \\
\hline \multicolumn{2}{|c|}{ Total by state order: } & \multicolumn{2}{|c|}{0} \\
\hline
\end{tabular}

Advanced training at the expense of individuals and legal entities

\begin{tabular}{clcc}
\hline 1 & Teachers of professional in advance higher & 1099 & full-time training \\
\cline { 3 - 4 } & education & 525 & distance form \\
\hline 2 & $\begin{array}{l}\text { Masters of industrial training of professional } \\
\text { (vocational) education }\end{array}$ & - & full-time training \\
\cline { 3 - 4 } & & 8 & correspondence form \\
\cline { 3 - 4 } & $\begin{array}{l}\text { Teachers of professional and theoretical } \\
\text { training of the institutions of professional } \\
\text { (vocational) education }\end{array}$ & 83 & full-time-distance form \\
\cline { 3 - 4 } & & 2 & full-time training \\
\hline Total: & & 1724 & full-time-distance form \\
\hline
\end{tabular}

To organize the continuous professional development of specialists through the technologies of formal and non-formal education, learning management system (LMS) "Profosvita" (2020) was opened. The professional significance of using LMS "Profosvita" (more than 4500 
participants are registered) as an educational and digital environment is to transform it from a linear to network (cluster) model of development of key, subject and interdisciplinary competencies, formation of European values and improving external communications between educational service providers, their customers and key stakeholders, developing skills to use digital tools, increase the amount of information, create their own digital products (Professional education, 2020). The use of the phenomenon of Network effect in the operation of the platform "Profosvita" is reflected in its scaling, openness, modular structure, asynchrony, adaptability and flexibility. The educational and digital environment of the "Profosvita" platform includes educational means developed and implemented on the basis of andragogical, interactive, digital and acmeological technologies. The educational location of the "Profosvita" platform accommodates categories of students of advanced training courses with personal web resources of tutors, teachers and content curators, based on digital educational courses. From January to June 2020 on the platform "Profosvita" research and teaching staff opened 60 web resources for students of advanced training courses by category (Figure 1): "Senior masters of professional (vocational) education" -2 web resources (3\%); "Masters of industrial training of professional (vocational) education" - 24 web resources (40\%); "Teachers of vocational and theoretical training of the institutions of professional (vocational) education" -14 web resources (23\%); "Teachers of professional higher education" - 20 web resources (34\%).

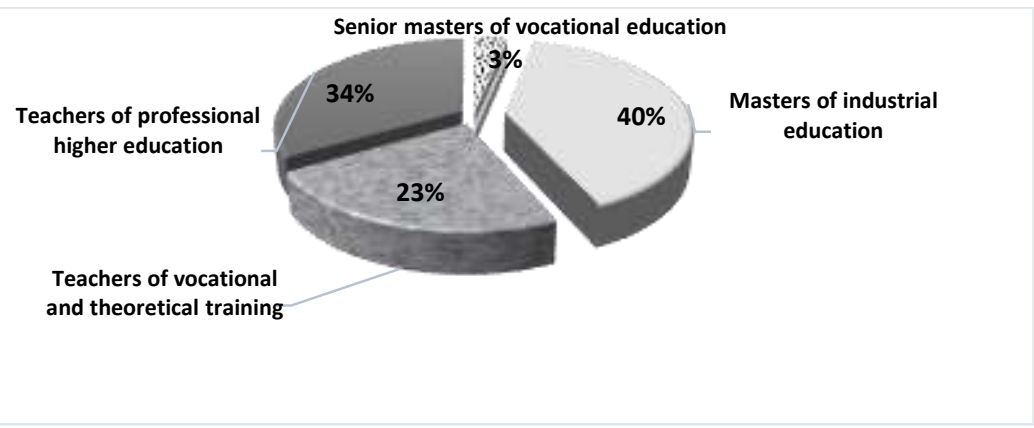

Figure $\mathbf{1}$ - Web resources for students of advanced training courses on the educational platform "Profosvita"

The structure of personal web resources of teachers is represented by the following components (Online Video Recruiting, 2020):

- $\quad$ organization of the educational process (instructional materials, which include information on the educational platform, class schedules, student registration cards, contact 
information of the tutor and group teachers, topics of graduation papers in the areas of departments, schedules of the educational process, stages of advanced training courses, etc.);

- $\quad$ training modules according to the curriculum (information is provided by group teachers according to schedules, contains materials for independent and individual work, questions for self-control, additional materials on the subject, etc.);

- $\quad$ aggregator of results on developed/improved competencies in the learning process;

- elements of feedback (chats, thematic forums, self-control tests, reflection questionnaires);

- $\quad$ other applications and programs for learning the material and practicing skills (including additional links).

From April 1, 2020, 26 web resources have been opened on the educational platform "Profosvita" for applicants for higher education at the "bachelor" and "master" level. The filling of these resources was carried out by the teaching staff, which provided the educational process in the conditions of quarantine measures. For each group of students, the moderator created a web resource "Organizational issues", which contains schedules, a list of students in the group, methodological materials to help applicants for higher education, a student forum, questionnaires for students.

In the conditions of quarantine measures for effective functioning of scientific and pedagogical workers and customers of educational services digital workplaces are created which provide presence of teachers in real time and give the chance to carry out online meetings. In particular, audio, video and webconferences, and based on the use of electronic document management, paperless digital technology, cloud technology and cyber security (Regulation on electronic educational..., 2019). Additionally, there are virtual communication platforms for online classes using video conferencing programs, including myownmeeting.net; Zoom; myownconference.com.ua; youtube.com, etc.

In order to provide scientific and methodological support for continuous professional development of specialists, providing them with methodological, organizational and advisory assistance in implementing pedagogical innovations, generalization of promising experience, mastering the latest production technologies created information and methodological resource "Methodical Treasury". A bank of the best pedagogical practices by professions has been formed, which includes: 
- lessons of professional-theoretical and professional-practical training;

- bank of materials of the best educational practices by professions (carpenter, machine operator of woodworking machines; mining professions; designer; confectioner; tailor; seamstress; the waiter, bartender; equipment of food enterprises; parlomaid, nurse; secretary of the head);

- instructional and technological cards, presentations;

- $\quad$ electronic portfolio "Public-private partnership in vocational education as a condition for the development of a competitive employee";

- control-analytical and other methodical materials that will help different categories of specialists in practice.

In the "Methodical Treasury" materials of the best educational practices are presented by institutions of professional (vocational) education of 24 regions of Ukraine (Figure 2).

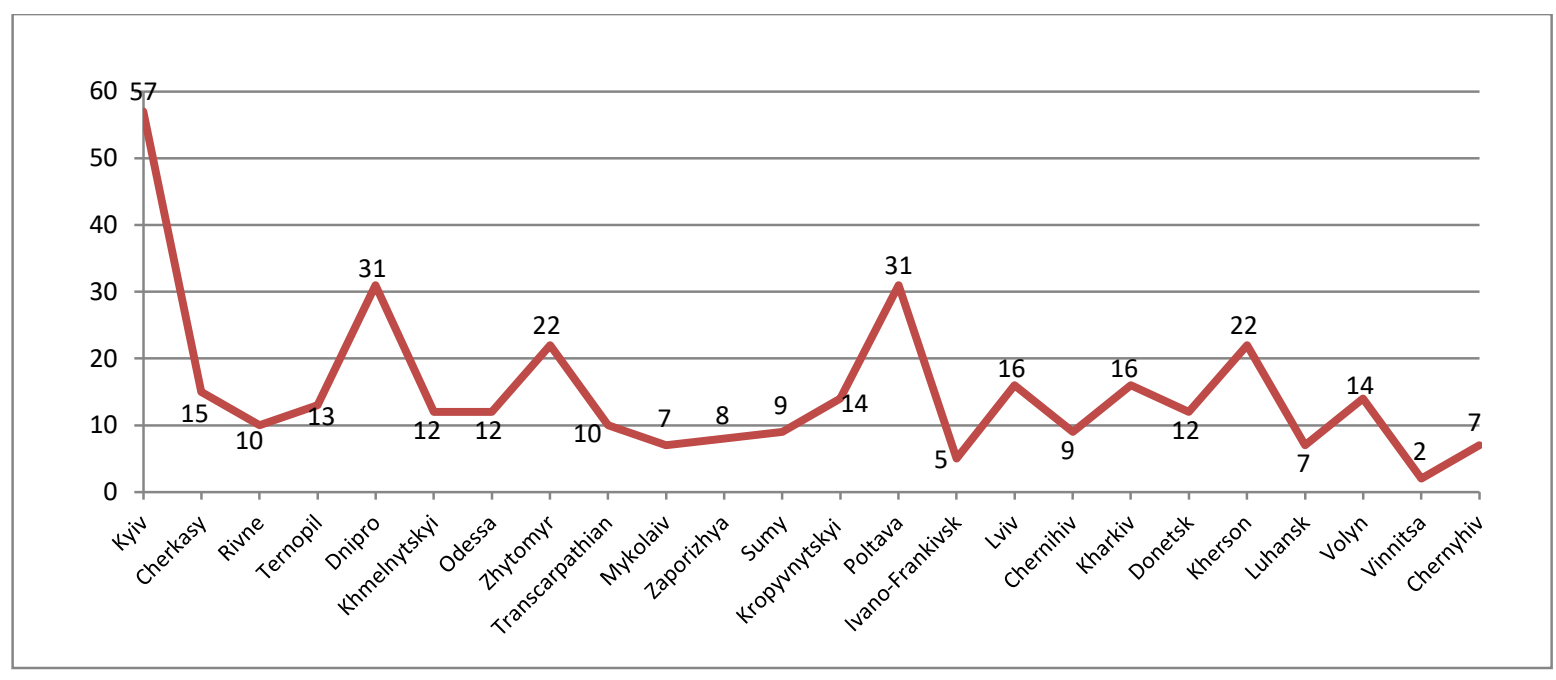

Figure 2 - Materials of the best educational practices of vocational education institutions in the informationmethodical resource "Methodical Treasury"

Multimedia information resources of modern production technologies have been created for the introduction of vocational education institutions into the educational process for 47 professions, which are trained in professional (vocational) education institutions, which include educational films, videos and 3D films. Information materials on the latest production technologies are also created based on the results of visiting specialized exhibitions.

In January 2020, the online consulting center "Latest Production Technologies" was opened for students of advanced training courses in various forms of education. The schedule of 
consultations is made. Participants of the consultations can get information about the latest technologies, best practices of teachers in various professions. Various non-formal education technologies are used for training and mutual learning of specialists. In particular, in 2020 on the basis of the Bila Tserkva Institute of Continuing Vocational Education there are: Corporate Team Building Studio, Online Academy of Digital Technologies, School of Pedagogical Coaching, School of Leaders of Vocational Education.

One of the forms of organization of professional development of specialists in non-formal education is the Virtual School of Pedagogical Coaching, which is open to the tasks of research work of the Institute and on the basis of the Scientific and Methodological Center of Vocational Education of Rivne region. The provision "On the virtual school of pedagogical coaching in the system of postgraduate education", the experimental curriculum for the development of psychological and pedagogical competence of specialists in the system of continuing professional education, the student's workbook “Development of psychological and pedagogical competence” were developed. Forms of study at the Virtual School of Pedagogical Coaching are face-to-face, distance. Among the types of classes are interactive lectures, workshops, webinars, trainings, practical classes, independent work. Participants of the Virtual School of Pedagogical Coaching completed an independent project "Designing your own trajectory of professional development". Analysis of questionnaires, workbooks of students of the Virtual School of Pedagogical Coaching shows the effectiveness of its work.

During April 2020, during the period of restrictive measures, an educational event with online broadcasting was organized every Thursday. 1.100 participants from 19 regions of Ukraine and the city of Kyiv were registered. During April 2020, 5 moderators worked in the educational event with online broadcasting. The following events were held: event forum "Self-coaching as a technology of self-leadership and management of professional change", master class "Bullying in the educational process: prevention and constructive overcoming (cyberbullying, selfie addiction, Internet addiction)", webinar "Application of distance learning technologies in the conditions of quarantine measures", master class "Modern education through the prism of the Theory of Generations", webinar "Smart complex for effective organization of classes in the system of professional (vocational) education".

During the first quarter of 2020, International and All-Ukrainian events were organized and held: discussion panel and international educational crowdsourcing at International exhibitions, 2 
International conferences, 3 All-Ukrainian conferences with online broadcasting, 47 international participants, more than 2600 domestic representatives of domestic educational institutions. In particular, the fifth anniversary International scientific-practical Internet conference "Psychological and pedagogical aspects of adult learning in the system of continuing education" was held. 124 reports from domestic and foreign educational institutions and organizations were presented. The conference was attended by more than 500 scientific and pedagogical staff, 30 foreign participants from Azerbaijan, Belarus, Georgia, Kazakhstan, Latvia, Estonia, Poland, USA, Finland.

On February 19, 2020, the All-Ukrainian coworking with online broadcasting was held: "The use of cloud technologies in the educational process of professional (vocational) education institutions". 150 educators attended the event from professional (vocational) educational institutions of Poltava, Donetsk, Kropyvnytskyi, Volyn, Zakarpattia, Odessa, Kherson, Sumy regions. 8 regional seminars, conferences, round tables, master classes were organized and held for teachers of professional (vocational and technical) education (Table 2).

Table 2 - Regional seminars, conferences, round tables, master classes

\begin{tabular}{|c|c|c|c|}
\hline No & Form and title of the event & Date & City \\
\hline 1 & $\begin{array}{l}\text { Master class "Using fairy tale therapy as a health technique in the work of } \\
\text { a teacher of a vocational education institution" }\end{array}$ & $\begin{array}{c}03 \\
\text { March }\end{array}$ & Severodonetsk \\
\hline 2 & $\begin{array}{l}\text { Round table "Development of professional competence of a teacher by } \\
\text { means of media educational technologies" }\end{array}$ & $\begin{array}{c}02 \\
\text { March }\end{array}$ & Mariupol \\
\hline 3 & $\begin{array}{l}\text { Scientific-practical seminar "Implementation of modern educational } \\
\text { practices in the training of skilled workers" }\end{array}$ & 15 April & $\begin{array}{l}\text { Horishni Plavni, } \\
\text { Poltava region }\end{array}$ \\
\hline 4 & $\begin{array}{l}\text { Round table "Labor protection of future skilled workers in the context of } \\
\text { European integration of Ukraine" }\end{array}$ & 16 April & Kropyvnytskyi \\
\hline 5 & $\begin{array}{l}\text { Scientific-practical seminar "Introduction of modern educational } \\
\text { technologies in the training of skilled workers" }\end{array}$ & 23 April & Kherson \\
\hline 6 & $\begin{array}{l}\text { Round table "Innovative educational technologies as a means of } \\
\text { humanizing the educational process" }\end{array}$ & 24 April & Kherson \\
\hline 7 & $\begin{array}{l}\text { Scientific-practical seminar "Implementation of promising pedagogical } \\
\text { experience in the training of skilled workers" }\end{array}$ & 21 May & Odessa \\
\hline 8 & $\begin{array}{l}\text { Round table "Legal bases of education of minors in institutions of } \\
\text { professional (vocational) education" }\end{array}$ & 22 May & $\begin{array}{l}\text { Pervomaisk, Mykolaiv } \\
\text { region }\end{array}$ \\
\hline
\end{tabular}

Carrying out of this type of actions allows involving experienced teachers-practitioners of Ukraine in an exchange of experience concerning actual questions of education, realization of educational innovations at preparation of competitive working shots. During this period, 96 
agreements (contracts) on cooperation with customers of educational services, 8 agreements with foreign educational institutions.

Quantitative absolute and relative indicators provided an opportunity to make their prompt adjustment and increase the level of satisfaction of customers (recipients) of educational services. Thus, as of June 2020, the answers provided by 625 respondents were summarized. The survey was conducted in groups of masters of industrial training and teachers of vocational and theoretical training of professional (vocational) education. The vast majority of respondents ( $85.7 \%)$ believe that the level of their professional competence after completing advanced training courses as a form of continuing education has increased significantly; $13.5 \%$ of respondents chose the option "increased insignificantly"; only $0.8 \%$ believe that it has remained unchanged (Figure 3).

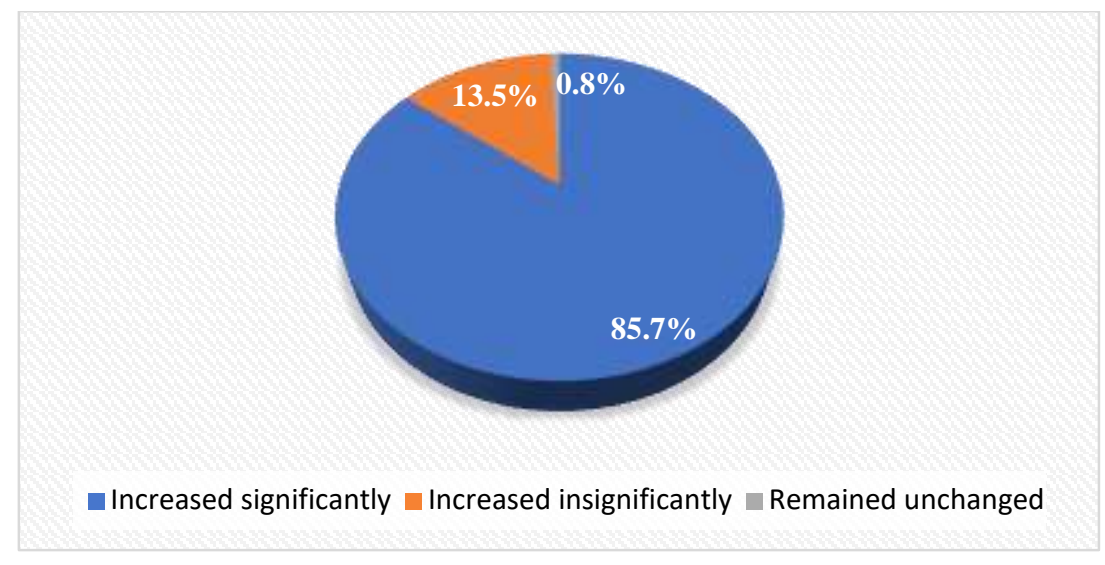

Figure 3 - The level of professional competence of specialists after passing advanced training courses

The results of diagnostics of the general level of achievement of results of training at advanced training courses of listeners also correlate with the received results. It should be noted that out of 625 respondents, $97.5 \%$ of respondents indicated the practical orientation of classes, the desire to use the acquired knowledge, skills and abilities in their further professional activities, $2.5 \%$ - found it difficult to answer (Figure 4). 


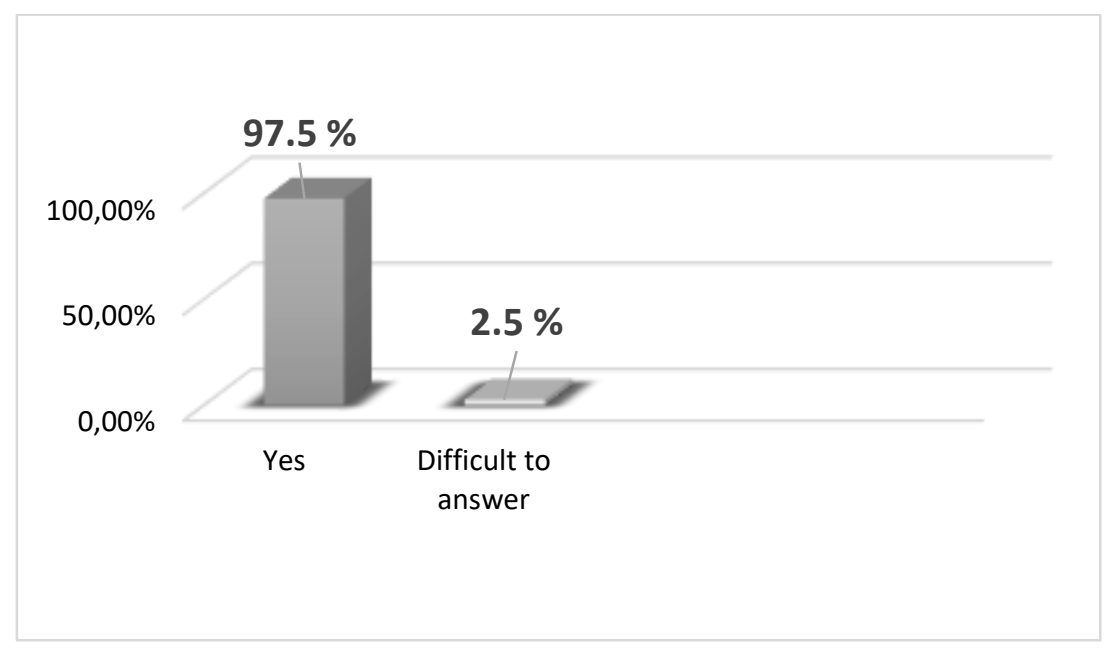

Figure 4 - Diagnosis of practical orientation in advanced training courses

The most productive respondents consider the following forms of formal education (Figure 5): exchange of perspective experience (85.8\%), seminars $71.6 \%$, theoretical classes, lectures (67.6\%), separate work on an individual educational trajectory (51.5\%), trainings, master classes $(45.4 \%)$, research work under the guidance of a teacher $(26.9 \%)$. The intensity of the educational process as a whole is considered optimal by $81.8 \%$, very high $-18.2 \%$.

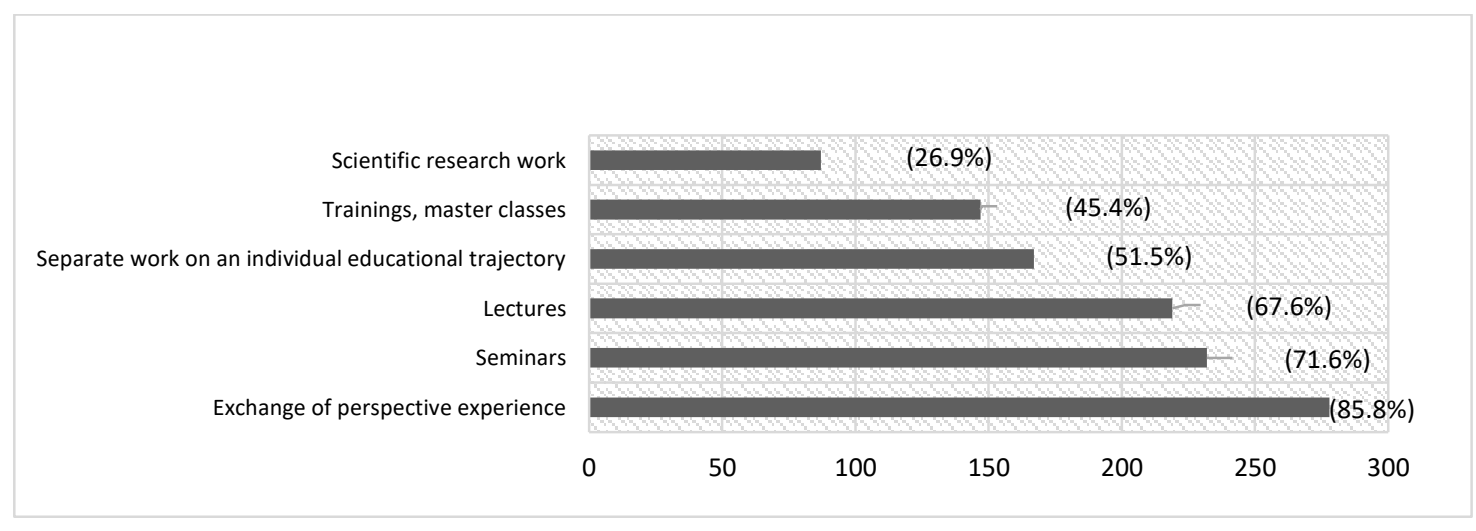

Figure 5 - Productive forms of formal education for continuous development of specialists

\section{CONCLUSIONS}

The creation of a single information and communication ecosystem at the Bila Tserkva Institute of Continuing Vocational Education, which combines the intellectual, scientific, professional, educational, technological potential of the subjects of the networked educational and digital environment, involved the use of digital, andragogy, acmeological and interactive technologies in cyberspace. The open content of the "Profosvita" platform had almost limitless opportunities to cover all categories of customers of educational services with access to non-formal education, employers, and key stakeholders, in the process of training, training, and retraining of specialists in various models and forms of education. 
The analysis of the received indicators testifies to a positive estimation of satisfaction of customers of educational services on advanced training courses. In order to comprehensively implement the program of research and experimental work, the solution of the tasks was planned and implemented a system of practice-oriented intercourse activities. Permanent monitoring of the quality of educational services makes it possible to assert the conformity of alternative models, forms of professional development to the needs and demands of customers of educational services, the feasibility of selection and use of formal and nonformal education technologies.

\section{ACKNOWLEDGEMENTS}

The results of the scientific search were obtained in accordance with the complex theme of research work of the Bila Tserkva Institute of Continuing Professional Education: "Improvement of modern models of vocational education teachers refresher training in the context of formation and development of professional competence" (Registration Number 0117U002381, 2017-2021).

\section{REFERENCES}

A Memorandum on Lifelong Learning. Commission of the European communities, 2000. Available at: http://arhiv.acs.si/dokumenti/Memorandum_on_Lifelong_Learning.pdf. Accessed date: 12 August 2020.

ANNEX to the Proposal for a Council Recommendation on Key Competences for Lifelong Learning, 2019. Available at: https://ec.europa.eu/education/sites/education/files/annex-recommendationkey-competences-lifelong-learning.pdf. Accessed date: 18 August 2020.

BURIBAYEV, Yermek; KHAMZINA, Zhanna. Gender equality in employment: The experience of Kazakhstan. International Journal of Discrimination and the Law, v. 19, n. 2, p. 110-124, 2019.

BURIBAYEV, Yermek; KHAMZINA, Zhanna; SUTEEVA, Canzada; APAKHAYEV, Nurlan; KUSSAINOV, Sergazy; BAITEKOVA, Kantkul. Legislative regulation of criminal liability for environmental crimes. Journal of Environmental Accounting and Management, v. 8, n. 4, p. 323-334, 2020.

Framework for updated key competences for lifelong learning, 2019. Available at: http://dlse.multycourse.com.ua/ua/page/15/53\#body-tab. Accessed date: 21 August 2020.

Government approves state standard for primary education, 2018. Available at: https://www.segodnya.ua/ukraine/pravitelstvo-utverdilo-gosudarstvennyy-standart-351. Accessed date: 16 August 2020. 
HRYSHCHENKO, Mykhailo. Concept New Ukrainian School. Kyiv: Ministry of Education and Science of Ukraine, 2017.

KHAMZINA, Zhanna; BURIBAYEV, Yermek; YERMUKANOV, Yerkin; ALSHURAZOVA, Aizhan. Is it possible to achieve gender equality in Kazakhstan: Focus on employment and social protection? International Journal of Discrimination and the Law, v. 20, n. 1, p. 5-20, 2020.

KNOWLES, Malcolm; HOLTON, Elwood; SWANSON, Richard. The adult learner: The definitive classic in adult education and human resource development. New York: Routledge, 2020.

Law of Ukraine No 1556-VII "On Higher Education", 2018. Available at: https://zakon.rada.gov.ua/laws/show/1556-18. Accessed date: 11 August 2020.

Law of Ukraine No 2145-VIII “On Education", 2017. Available at: https://zakon.rada.gov.ua/laws/show/2145-19. Accessed date: 14 August 2020.

Learning management system (LMS) “Profosvita", 2020. Available at: https://profosvita.org/. Accessed date: 11 August 2020.

LUCENA, S.; OLIVEIRA, J. M. A. Culturas digitais na educação do Século XXI. Revista Tempos e Espaços em Educação, v. 7, n. 14, p. 35-44, 2014.

Online Video Recruiting, 2020. Available at: https://ovr.com.ua. Accessed date: 26 August 2020.

Professional education, 2020. Available at: https://profosvita.org. Accessed date: 23 August 2020.

PARASKEVA, J. M. "Brutti, Sporchi \& Cattivi": Towards a Non-Abyssal Curriculum. Revista Tempos e Espaços em Educação, v. 9, n. 18, p. 75-90, 2016.

PEREIRA, A. A educação de jovens e adultos no sistema prisional brasileiro: o que dizem os planos estaduais de educação em prisões?. Revista Tempos e Espaços em Educação, v. 11, n. 24, p. 245252, 2018.

Regulation on electronic educational resources of the Ministry of Education and Science of Ukraine, 2019. Available at: https://mon.gov.ua/ua/news/mon-proponuye-dlya-gromadskogoobgovorennya-proekt-nakazu-pro-vnesennya-zmin-do-polozhennya-pro-elektronni-osvitni-resursi.

Accessed date: 18 August 2020.

RIDHO, Taridi; VINICHENKO, Mikhail; MAKUSHKIN, Sergey. Participation of companies in emerging markets to the sustainable development goals (SDGS). Economic and Social Development, v. 1, p. 741-752, 2018.

State standard of Ukraine No 2481-94. Information processing systems. Intelligent information technology. Terms and definitions, 2014. Available at: http://online.budstandart.com/ua/catalog/doc-page.html?id_doc=79130. Accessed date: 03 August 2020. 
SYDORENKO, Viktoriia; DENYSOVA, Alla. Regulations on the organization of the educational process by distance learning at the Bila Tserkva Institute of Continuing Vocational Education. AgroEducation, v. 3, p. 26-32, 2020.

SYDORENKO, Viktoriia; PONOMAREVSKYI, Artem. Professional media competence development for teachers of foreign languages by means of continuing education courses: Theoretical principles. In: Association agreement from partnership to cooperation. Hamilton: Accent Graphics Communication Publishing, 2018. p. 187-194.

SYDORENKO, Viktoriia. Acmeological technologies in adult education. Scientific Journal of the National Pedagogical University named after M.P. Drahomanov, v. 26, n. 36, p. 38-42, 2016.

SYDORENKO, Viktoriia. Reforming the system of improvement of qualification of heads of educational establishments in conditions of implementation of the Concept "New Ukrainian School". In: Head of the New Ukrainian School: Ideological and professional orientations. Kyiv: NPU named after M.P. Drahomanov, 2017. p. 148-153.

SYDORENKO, Viktoriia. Regulations on the virtual department of andragogy. Agro-Education, v. 12, p. 187-194, 2018.

The concept of implementation of state policy in the field of vocational (vocational) education "Modern vocational (vocational) education" for the period up to 2027 No 419-2019-p, 2019. Available at: https://zakon.rada.gov.ua/laws/show/419-2019-\%D1\%80. Accessed date: 11 August 2020.

Towards an institutional strategy for Lifelong Learning Higher Professional Education, 2012. Available at: www.aqu.cat/doc/doc_16974883_1.pdf. Accessed date: 19 August 2020.

VINICHENKO, Mikhail; CHULANOVA, Oxana; KARACSONY, Peter; BOGDAN, Elena; MELNICHUK, Alexander; MAKUSHKIN, Sergey. Model of competences of graduates of high schools of engineering directions: research of stakeholders. Modern Journal of Language Teaching Methods, v. 8, n. 3, p. 369-380, 2018a.

VINICHENKO, Mikhail; CHULANOVA, Oxana; OSEEV, Anatoly; BOGDAN, Elena; MAKUSHKIN, Sergey; GRISHAN, Mikhail. Interaction of the higher education and key employer for the formation of the actual profile of the competences of graduates of engineering directions. Modern Journal of Language Teaching Methods, v. 8, n. 5, p. 394-404, 2018b.

VINICHENKO, Mikhail; KARACSONY, Peter; KIRILLOV, Alexander; OSEEV, Anatoly; CHULANOVA, Oxana; MAKUSHKIN, Sergey; SHALASHNIKOVA, Valentina. Influence of time management on the state of health of students and the quality of their life. Modern Journal of Language Teaching Methods, v. 8, n. 5, p. 166-184, 2018c.

VINICHENKO, Mikhail; MELNICHUK, Alexander; MAKUSHKIN, Sergey. Implementation of game methods in the preparation of management personnel. In: 4th international conference on higher education advances (head'18). Valencia: Universitat Politécnica de Valencia, 2018d. p. 373-380. 


\section{ABOUT THE AUTHORS}

\section{Viktoriia Sydorenko}

Full Doctor in Education, Bila Tserkva Institute of Continuing Professional Education, University of Educational Management, Bila Tserkva, Ukraine.

E-mail: sydorenko.vik32@ust-hk.com.cn

ORCID: https://orcid.org/0000-0002-6626-4581

\section{Inna Shorobura}

Full Doctor in Pedagogy, Professor, Department of Pedagogy, Khmelnytskyi Humanitarian and Pedagogical Academy, Khmelnytskyi, Ukraine.

E-mail: shorobura5514-2@murdoch.in

ORCID: https://orcid.org/0000-0003-3728-7968

\section{Anna Ponomarenko}

$\mathrm{PhD}$ in Education, Department of Postgraduate Education, National Academy of the Security Service of Ukraine, Kyiv, Ukraine.

E-mail: a.ponomarenko5514-2@ubogazici.in

ORCID: https://orcid.org/0000-0002-7357-2929

\section{Maryna Dei}

PhD in Law, Associate Professor, Department of Constitutional and Administrative Law, National Aviation University, Kyiv, Ukraine.

E-mail: m.dei5514-2@national-univesity.info

ORCID: https://orcid.org/0000-0002-0626-8089

\section{Oksana Dzhus}

Full Doctor in Pedagogy, Department of Professional Education and Innovative Technologies, Vasyl Stefanyk Precarpathian National University, Ivano-Frankivsk, Ukraine.

E-mail: o.v.dzhus5514-2@unesp.co.uk

ORCID: https://orcid.org/0000-0001-9363-689X 